\title{
Efek Konsumsi Air Kelapa (Cocos nucifera) terhadap Ketahanan Berolahraga Selama Latihan Lari pada Laki-laki Dewasa Bukan Atlet
}

\author{
Fen Tih, Harijadi Pramono, Stella Tinia Hasianna, Ersalina Tresnawati Naryanto, \\ Albertus Gani Haryono, Oliver Rachman \\ Fakultas Kedokteran, Universitas Kristen Maranatha Bandung
}

\begin{abstract}
Abstrak
Ketahanan berolahraga menunjang latihan fisik yang optimal untuk meningkatkan derajat kesehatan dan kebugaran jasmani. Penurunan kapasitas ketahanan olahraga disebabkan oleh dehidrasi dan penurunan karbohidrat dalam otot selama melakukan latihan. Air kelapa berpotensi sebagai minuman olahraga karena memiliki derajat keasaman yang rendah, gula seimbang, kandungan mineral, dan bersifat isotonis. Penelitian ini bertujuan mengetahui efek konsumsi air kelapa terhadap ketahanan dan kebugaran berolahraga diukur dari jarak tempuh dan $\mathrm{VO}_{2}$ max selama latihan lari. Penelitian dilakukan di Lapangan FPOK UPI Bandung periode Juli 2015-Februari 2016. Bahan penelitian yang digunakan adalah air kelapa dalam kemasan. Air mineral, air gula 5\%, dan minuman olahraga isotonik yang digunakan sebagai pembanding. Subjek penelitian adalah 120 orang laki-laki, berusia 18-23 tahun yang dibagi menjadi 4 kelompok untuk tiap-tiap bahan uji. Setelah pemanasan, subjek berlari secepatnya selama 30 menit. Bahan uji diberikan sebelum dan setiap 10 menit selama lari. Jarak yang ditempuh dicatat dalam satuan meter. Analisis dengan one-way ANOVA yang dilanjutkan dengan uji least significant difference (LSD) dengan $\alpha<0,05$. Jarak tempuh terpanjang rata-rata dan $\mathrm{VO}_{2}$ max tertinggi didapatkan pada kelompok perlakuan air kelapa, diikuti kelompok air gula $5 \%$, minuman olahraga isotonik, dan air mineral $(\mathrm{p}<0,01)$. Simpulan, konsumsi air kelapa sebelum dan selama latihan olahraga lari dapat meningkatkan ketahanan olahraga pada laki-laki dewasa bukan atlet.
\end{abstract}

Kata kunci: Air kelapa, ketahanan olahraga, latihan lari

\section{The Effects of Coconut Water (Cocos nucifera) Consumption towards Endurance During Running Exercise on Non-Athlete Adult Male}

\begin{abstract}
The endurance in exercising supports optimal physical training to improve physical health and fitness. Two major factors in decreasing sport endurance are dehydration and loss of carbohydrates in muscle during exercise. Coconut water is a potential sports drink because it has low acidity, sugars, minerals content and is isotonic. This research aims to know the effects of coconut water consumption towards endurance and fitness measured from $\mathrm{VO}_{2}$ max and mileage during running exercise. The study was conducted in FPOK UPI Bandung during July 2015 to February 2016. Research material used was coconut water, mineral water, $5 \%$ sugar water, and isotonic sports drink. The subjects were 120 men, aged 18-23 years old, divided into 4 groups for each of the test material. After warming up, the subjects ran quickly for 30 minutes. Test materials were given before and every 10 minutes during the run. Distance traveled was recorded in units of meters. Data was analyzed using one-way ANOVA test followed by the least significant difference (LSD) test with $\alpha<0.05$. The longest distance and highest $\mathrm{VO}_{2}$ max were obtained by the group treated with coconut water, followed by $5 \%$ sugar water, isotonic sports drinks, and mineral waters $(\mathrm{p}<0.01)$. In conclusion, coconut water consumption before and during exercise can improve sports endurance on non-athlete adult male.
\end{abstract}

Key words: Coconut water, running exercise, sport endurance

Korespondensi: Fen Tih, dr., M.Kes. Fakultas Kedokteran, Universitas Kristen Maranatha. Jl. Prof. drg. Suria Sumantri, MPH No. 65, Bandung 40164 Indonesia. E-mail: fentihfk@gmail.com 


\section{Pendahuluan}

Kesehatan merupakan kondisi baik fisik, mental, spiritual maupun sosial yang memungkinkan setiap orang dapat hidup produktif secara sosial dan juga ekonomis. Kesehatan fisik ditandai dengan kebugaran jasmani, yaitu kemampuan tubuh seseorang untuk melakukan pekerjaan sehari-hari tanpa menyebabkan kelelahan yang berarti. Kebugaran jasmani yang baik dapat dicapai dengan meningkatkan aktivitas fisik dan melakukan latihan fisikatau olahraga terprogram secara baik, benar, terukur, dan teratur. Latihan fisik menurunkan risiko penyakit degeneratif, meningkatkan kapasitas jantung, mencegah tekanan darah tinggi, memperbaiki profil lipid darah, mencegah osteoporosis, memperbaiki fleksibilitas otot dan sendi, serta meningkatkan sistem kekebalan tubuh. Selain manfaat fisik, latihan fisik juga memiliki manfaat psikologis karena dapat membantu mengendalikan stres, dan mengurangi kecemasan serta depresi. ${ }^{1}$

Latihan fisik yang baik, benar, terukur, dan teratur dapat memberikan hasil optimal untuk meningkatkan derajat kesehatan dan kebugaran jasmani. Latihan fisik itu sebaiknya dilakukan secara teratur 3 sampai 5 kali dalam seminggu, dimulai dari pemanasan dengan peregangan 10-15 menit, dilanjutkan dengan latihan 2060 menit, dan diakhiri pendinginan dengan peregangan selama 5 sampai 10 menit. Seseorang dapat melakukan latihan fisik yang optimal bila memiliki kapasitas ketahanan berolahraga yang baik. Penurunan kapasitas ketahanan olahraga seseorang terutama disebabkan oleh dehidrasi dan penurunan karbohidrat dalam otot selama melakukan latihan. ${ }^{1,2}$

Asupan minuman yang memiliki elektrolit disertai dengan karbohidrat yang telah memadai akan mempertahankan homeostasis, mencegah masalah kesehatan, dan juga mengoptimalisasi performa. Untuk mencegah kekurangan cairan dianjurkan minum air sebelum, selama, dan setelah olahraga. Asupan cairan yang adekuat melalui air minum sangat penting agar performa optimal.2,3

Pada umumnya orang akan minum air biasa selama berolahraga, tetapi akan menyebabkan hiponatremia karena jumlah air dan natrium menjadi tidak seimbang. Minuman olahraga yang mengandung karbohidrat-elektrolit lebih dianjurkan dan umumnya sebagai pilihan para atlet. Sebagian orang lebih menyukai alternatif alami karena minuman olahraga mengandung fruktosa, maltodekstrin, pemanis, juga esens buatan disertai elektrolit tambahan yang dapat mengganggu kontraksi otot. Fruktosa tinggi dapat menimbulkan gangguan gastrointestinal dan mengakibatkan diare osmotik. Alternatif minuman untuk olahraga alami yang paling tepat adalah air kelapa yang kaya akan kandungan kalium, natrium, klorida, dan karbohidrat. ${ }^{3,4}$

Air kelapa merupakan salah satu hasil alam yang paling bermanfaat. Air kelapa merupakan cairan jernih dalam kelapa muda yang memiliki nilai nutrisi dan manfaat terapeutik yang tinggi. Air kelapa dapat digunakan sebagai alternatif rehidrasi secara oral, bahkan di daerah terpencil yang dapat dipergunakan untuk rehidrasi secara intravena. Air kelapa mengandung elektrolityang tinggi dan bersifat isotonis. Kandungan natrium dan kalium dapat mengembalikan elektrolit yang hilang melalui keringat dan urine. Air kelapa berasa sedikit manis sehingga dapat mengurangi mual, kembung, dan rasa tidak nyaman di perut sehingga mudah diminum dalam jumlah lebih banyak dibanding dengan minuman olahraga atau air minum biasa. Keasaman yang rendah, gula seimbang, kandungan mineral, dan sifat isotonis menjadikan air kelapa itu potensial dikonsumsi sebagai minuman olahraga. ${ }^{5,6}$

Penelitian ini mempunyai tujuan menilai efek konsumsi air kelapa terhadap kebugaran serta ketahanan berolahraga diukur dari jarak tempuh dan $\mathrm{VO}_{2} \max$ selama latihan lari pada laki-laki dewasa bukan atlet.

\section{Metode}

Penelitian ini merupakan eksperimental kuasi yang bersifat komparatif. Penelitian dilakukan di Lapangan Fakultas Pendidikan Olahraga dan Kesehatan Universitas Pendidikan Indonesia (FPOK UPI) selama Juli 2015 sampai Februari 2016. Bahan penelitian yang digunakan adalah air kelapa dalam kemasan. Sebagai pembanding dipergunakan air mineral, air gula $5 \%$, dan juga minuman olahraga isotonik. Air gula $5 \%$ dibuat dengan melarutkan 5 gram gula putih dalam $100 \mathrm{~mL}$ air. Minuman olahraga isotonik yang digunakan mengandung gula $6,7 \%$; natrium 49 mg\%; kalium 20 mg\%; dan elektrolit.

Subjek penelitian ini adalah 120 orang lakilaki bukan atlet; berusia 18-23 tahun; BMI 18-22,9; dan rutin berolahraga minimal 1 kali per minggu. Subjek dibagi menjadi 4 kelompok 
untuk tiap-tiap bahan uji. Saat penelitian, subjek dalam kondisi sehat dan telah menandatangani persetujuan ikut dalam penelitian (informed consent). Subjek dieksklusi bilamana melakukan aktivitas berlebihan yang akan melelahkan otot, mengonsumsi minuman penambah bagi stamina 24 jam sebelum penelitian, dan juga memiliki riwayat penyakit asma, jantung, hipertensi, diabetes melitus, atau pun merokok. Sebelum penelitian ini dilaksanakan, subjek beraktivitas seperti biasa dan tidak melakukan kegiatan yang dapat menyebabkan kelelahan otot, serta tidak mengonsumsi kopi, coklat, alkohol, dan minuman penambah stamina.

Latihan lari dilaksanakan di lintasan lari sepanjang 400 meter. Sebelum latihan, subjek melakukan pemanasan (stretching) selama 10 menit. Bahan uji diberikan sebanyak $300 \mathrm{~mL}$, kemudian subjek penelitian ini diminta berlari secepatnya selama 30 menit. Selama berlari, setiap 10 menit bahan uji diberikan lagi sebanyak $300 \mathrm{~mL}$. Jarak yang ditempuh dalam 30 menit lalu dicatat dalam satuan meter. Perhitungan $\mathrm{VO}_{2}$ max dengan mempergunakan rumus yang disarankan oleh Frank Horwill, ${ }^{7}$ yaitu $\mathrm{VO}_{2} \max =$ $[\{($ jarak yang ditempuh $/ 15)-133\} \times 0,172]+33,3$.

Jarak tempuh lari rata-rata dalam 30 menit untuk dapat mengukur ketahanan dan $\mathrm{VO}_{2} \max$ subjek penelitian dilakukan pada ke-4 kelompok. Bahan uji dianalisis dengan one-way ANOVA yang dilanjutkan dengan uji least significant difference (LSD) dengan $\alpha<0,05$.

\section{Hasil}

Hasil pengukuran jarak tempuh lari selama 30 menit dan $\mathrm{VO}_{2} \max$ subjek penelitian setelah diberi perlakuan air kelapa, air mineral, air gula $5 \%$, dan minuman olahraga isotonik ditampilkan pada Tabel 1 .

Jarak tempuh rata-rata yang paling panjang didapatkan pada kelompok dengan perlakuan air kelapa, diikuti dengan kelompok air gula $5 \%$ dan minuman olahraga isotonik, sedangkan yang terendah pada pemberian air mineral. Uji one-way ANOVA menunjukkan perbedaan yang sangat signifikan jarak tempuh lari rata-rata keempat kelompok perlakuan $(\mathrm{p}<0,01)$. Hasil analisis dengan LSD menunjukkan perbedaan sangat bermakna antara jarak tempuh lari ratarata kelompok perlakuan air kelapa dengan ketiga kelompok perlakuan lainnya. Konsumsi minuman olahraga isotonik tidak menghasilkan jarak tempuh yang berbeda berdasarkan statistik dengan konsumsi air gula $5 \%(\mathrm{p}>0,05)$.

Seperti jarak tempuh lari, $\mathrm{VO}_{2} \max$ rata-rata tertinggi didapatkan pada kelompok perlakuan air kelapa, diikuti dengan kelompok air gula $5 \%$, minuman olahraga isotonik, dan air mineral. Uji one-way ANOVA menunjukkan perbedaan yang sangat signifikan antara $\mathrm{VO}_{2} \max$ rata-rata keempat kelompok perlakuan $(\mathrm{p}<0,01)$. Hasil analisis dengan LSD menunjukkan perbedaan yang sangat bermakna antara $\mathrm{VO}_{2}$ max ratarata kelompok perlakuan air kelapa dan ketiga kelompok perlakuan lainnya. $\mathrm{VO}_{2} \max$ rata-rata kelompok perlakuan minuman olahraga isotonik tidak berbeda secara statistik dengan kelompok perlakuan air gula $5 \%$ dan air mineral $(\mathrm{p}>0,05)$.

\section{Pembahasan}

Hasil dari penelitian ini memperlihatkan bahwa konsumsi air kelapa untuk persiapan sebelum dan rehidrasi selama latihan olahraga dapat meningkatkan ketahanan (endurance) dengan jarak tempuh lari yang lebih panjang dibanding dengan konsumsi air mineral, air gula $5 \%$, atau minuman olahraga yang isotonik. Konsumsi air kelapa juga meningkatkan kebugaran jasmani yang ditandai tingkat $\mathrm{VO}_{2}$ max yang lebih tinggi dibanding dengan kelompok lain.

Penelitian oleh Aragon-Vargas dan MadrizDavila $^{8}$ melibatkan 19 orang subjek penelitian yang melaksanakan olahraga di luar ruangan selama 20 menit sampai berat badan berkurang sebanyak 2\%, kemudian direhidrasi sebanyak 125\% kehilangan berat badan dengan air minum biasa, minuman olahraga, atau air kelapa. Hasil penelitian menunjukkan bahwa air kelapa dan minuman olahraga lebih efektif daripada air untuk mengembalikan volume cairan tubuh.

Tabel 1 Jarak Tempuh dan VO $\max$ Rata-rata pada Empat Perlakuan

\begin{tabular}{lcccc}
\hline & Air Kelapa & $\begin{array}{c}\text { Minuman Olahraga } \\
\text { Isotonik }\end{array}$ & Air Gula 5\% & Air Mineral \\
\hline Jarak tempuh (m) & $5.807,33$ & $5 \cdot 347,73$ & $5 \cdot 529,83$ & $4.913,00$ \\
$\mathrm{VO}_{2}$ max & 43,59 & 38,75 & 40,64 & 37,39 \\
\hline
\end{tabular}


Penelitian oleh Saat dkk. ${ }^{9}$ membandingkan air yang biasa, minuman yang mengandung karbohidrat-elektrolit, dan air kelapa untuk rehidrasi setelah latihan sampai $60 \% \mathrm{VO}_{2} \max$ di suhu ruang $31,1^{\circ} \mathrm{C}$ selama 90 menit sampai berat badannya berkurang $2,5-3 \%$. Rehidrasi diberikan 120\% dari kehilangan berat badan. Parameter yang diukur adalah hemoglobin, hematokrit, osmolalitas serta elektrolit serum, urine, dan juga berat badan. Hasil penelitian menunjukkan bahwa rehidrasi menggunakan air biasa ternyata menyebabkan dilusi darah disebabkan oleh karena penurunan osmolalitas darah dan urine, sedangkan rehidrasi dengan minuman mengandung karbohidrat-elektrolit menjaga osmolalitas.

Penelitian lain dengan latihan hingga 65\% $\mathrm{VO}_{2}$ max selama 90 menit pada suhu ruangan $32^{\circ} \mathrm{C}$ sampai berat badannya berkurang $3 \%$, mempergunakan air biasa, minuman olahraga, dan juga air kelapa untuk rehidrasi hingga 120\% kehilangan berat badan. Rehidrasi dengan air biasa menurunkan osmolalitas serum dan urine, serta kadar glukosa darah, sedangkan air kelapa sama efektif dengan minuman olahraga dalam proses rehidrasi. ${ }^{10}$

Pemberian air kelapa sebelum dan juga selama latihan dilakukan oleh Laitano dkk.11 Subjek penelitian diberi air biasa, minuman beresens jeruk, atau air kelapa 1 jam sebelum latihan bersepeda sampai terjadi kelelahan. Pemberian minuman sebanyak $10 \mathrm{~mL} / \mathrm{kgBB}$ dilanjutkan selama latihan setiap 10 menit. Hasilnya menunjukkan pemberian air kelapa menurunkan volume urine dan meningkatkan kapasitas olahraga dibanding dengan air biasa dan minuman berperisa jeruk.

Metode penelitian lain dilakukan oleh Kalman dkk. ${ }^{4}$ Penelitian ini membandingkan air mineral, air kelapa, konsentrat air kelapa, dan minuman karbohidrat-elektrolit untuk rehidrasi setelah latihan dengan treadmill untuk waktu 30 menit. Setelah rehidrasi, latihan itu dilanjutkan hingga subjek kelelahan. Parameter yang diteliti adalah berat badan, osmolalitas plasma, dan berat jenis urine. Hasil yang diperoleh menunjukkan air kelapa dan konsentrat air kelapa sama efektif dengan minuman karbohidrat-elektrolit.

Pada penelitian ini minuman untuk olahraga isotonik tidak meningkatkan jarak tempuh lari dan tingkat $\mathrm{VO}_{2} \max$ secara signifikan pada subjek dibanding dengan pemberian air gula $5 \%$, kemungkinan disebabkan oleh kadar gula dalam minuman olahraga isotonik yang mencapai 6,7\% mengganggu kecepatan pengosongan lambung.

Dehidrasi dan cadangan karbohidrat yang berkurang adalah dua faktor utama penyebab penurunan performa tubuh saat berolahraga. Individu yang memulai latihan dengan level hidrasi tubuh yang baik akan dapat mempunyai performa daya tahan (endurance), kecepatan respons atau reaksi, dan performa berolahraga yang lebih prima. Kelelahan dapat terjadi karena cadangan energi yang berasal dari ATP menipis, yaitu kreatin fosfat, glikogen atau glukosa, dan akumulasi laktat pada otot. Ketidakseimbangan homeostasis misalnya pada gangguan volume dan osmolalitas plasma, penurunan $\mathrm{pH}$ darah dan kadar elektrolit cairan tubuh, serta kapasitas kerja sistem neuromuskular yang berkurang juga dapat mempercepat kelelahan. ${ }^{2}$

Cairan yang keluar dari keringat selama berolahraga dapat lebih dari satu liter per jam sehingga bilatidak diberikan rehidrasi, seseorang dapat mengalami dehidrasi, terutama bila suhu lingkungannya panas. Dehidrasi dan penurunan volume cairan ekstraseluler akan menurunkan volume darah sementara itu otot yang sedang bekerja memerlukan suplai darah yang banyak untuk mampu mencukupi kebutuhan oksigen. Aliran darah ke kulit untuk pelepasan panas juga meningkat selama olahraga. Ekskresi keringat akan menurunkan volume cairan ekstraseluler yang mengakibatkan peningkatan sementara kadar ion natrium. Keadaan ini merangsang osmoreseptor sehingga terjadi sekresi hormon antidiuretik yang menimbulkan rasa haus dan mengurangi diuresis. Rehidrasi akan mengoreksi keadaan ini. Rehidrasi akan mengoreksi keadaan hipovolemia sehingga respons hemodinamiknya lebih baik serta menurunkan aktivitas sistem simpatis yang terjadi saat dehidrasi. ${ }^{6}$

Selama berolahraga, seseorang memerlukan asupan air dengan kandungan karbohidrat dan elektrolituntuk mempertahankan keseimbangan cairan tubuh. Asupan cairan direkomendasikan sebelum, selama, dan setelah latihan terutama bila olahraga dilakukan di tempat yang panas dan lembap disebabkan oleh kehilangan cairan tubuh akan lebih banyak. Minuman yang mengandung karbohidrat-elektrolit meningkatkan performa bila dikonsumsi sebelum dan selama olahraga. Karbohidrat itu meningkatkan performa dengan mengganti cadangan karbohidrat dalam tubuh dan merupakan bahan bakar yang utama selama latihan ketahanan berolahraga. Minuman yang 
dianjurkan adalah yang mengandung elektrolit dan karbohidrat 2,5-6,9\%. ${ }^{2-4,6,12}$

Buah kelapa berbentuk eliptik dan memiliki 3 lapisan. Bagian paling luar disebut perikarp, sedangkan lapisan kedua yang bersifat fibrosa disebut mesokarp. Lapisan keras paling dalam yang disebut endokarp dan menutupi daging buah kelapa (endosperm). Rongga di dalam endosperm ini mengandung air kelapa. Bagian endosperm membentuk gel ketika buah kelapa berusia 5-6 bulan, semakin keras dan berwarna putih pada saat kelapa bertambah matang/tua, dan tengahnya berisi air kelapa. Kelapa muda sekitar 6-9 bulan mengandung $750 \mathrm{~mL}$ air kelapa. Kandungan mineral dan gula dalam air kelapa menyebabkan air kelapa bersifat isotonis secara alami sehingga ideal untuk rehidrasi dan menyegarkan setelah latihan fisik. ${ }^{6}$

Air kelapa mengandung senyawa fitohormon sitokinin, kinetin, transzeatin yang memiliki efek anti-aging, antikanker, dan antitrombotik. Kandungan vitamin dan ion anorganik bekerja sebagai antioksidan untuk netralisasi produksi ROS pada saat terjadi hipermetabolisme seperti pada saat berolahraga. Ion anorganik bertindak sebagai donor elektron atau sebagai bagian dari metaloenzim, contohnya selenium merupakan bagian dari glutation peroksidase serta $\mathrm{Zn}$ dan $\mathrm{Cu}$ adalah bagian dari superoxide dismutase (SOD)..$^{3-6}$

Ion dalam air kelapa dapat menggantikan elektrolit tubuh yang diekskresikan melewati keringat, seperti natrium, kalium, magnesium, dan kalsium sehingga dapat digunakan sebagai minuman untuk rehidrasi. Konsentrasi elektrolit dalam air kelapa menimbulkan tekanan osmotik yang mirip dengan cairan tubuh, tetapi tidak memengaruhi hemostasis (koagulasi plasma). Air kelapa sangat kompatibel untuk tubuh, dapat mengganti elektrolit, menurunkan suhu tubuh, dan membantu performa olahraga. Kandungan air kelapa dijelaskan pada Tabel 2.5-6

Fraksi utama yang terlarut dalam air kelapa adalah gula, yaitu sukrosa, sorbitol, glukosa, fruktosa, galaktosa, xilosa, dan juga manosa. Gula merupakan sumber energi untuk kontraksinya otot. Vitamin yang dikandung adalah B1, B2, B3, B5, B6, B7, dan B9. Vitamin-vitamin ini berperan penting dalam metabolisme energi seluler. Kalium merupakan kation intrasel yang paling penting dan berperan mengatur denyut jantung dan fungsi otot. Asupan K+ diperlukan untuk mengganti $\mathrm{K}+$ yang hilang dari urine dan keringat karena kontrol metabolisme ion $\mathrm{K}+$ tidak memiliki mekanisme konversi metabolik seperti pada ion $\mathrm{Na}^{+} .2,6$

Natrium merupakan kation di ekstraseluler utama yang akan menurun selama berolahraga disebabkan banyak diekskresi melalui keringat dan urine. Magnesium akan mempertahankan potensi elektrik dalam sel otot dan mencegah kelebihan kalsium, sedangkan fosfor dan kalsium dibutuhkan dalam proses kontraksi otot. Ferum berperan dalam transpor oksigen ke seluruh tubuh dan metabolisme energi. Kuprum penting pada respirasi sel dan sintesis neurotransmiter. Ion klorida dan $\mathrm{HCO}_{3}{ }^{-}$dapat mempertahankan $\mathrm{pH}$ darah. Air kelapa juga mengandung banyak asam amino sebagai sumber energi selama latihan. ${ }^{6}$

\section{Simpulan}

Konsumsi air kelapa sebelum dan selama latihan

Tabel 2 Kandungan Air Kelapa

\begin{tabular}{lclcll}
\hline Kandungan & $\mathbf{g / 1 0 0} \mathbf{g}$ & Ion & $\mathbf{m g} / \mathbf{1 0 0} \mathbf{g}$ & \multicolumn{2}{c}{ Asam Amino } \\
\hline Air & 94,180 & $\mathrm{Ca}$ & 27,35 & Alanin & Lisin \\
Protein & 0,120 & $\mathrm{Fe}$ & 0,02 & Arginin & Metionin \\
Lipid & 0,073 & $\mathrm{Mg}$ & 6,40 & Aspartat & Fenilalanin \\
Gula & 5,230 & $\mathrm{P}$ & 4,66 & Glutamat & Prolin \\
$\mathrm{pH}$ & 4,700 & $\mathrm{~K}$ & 203,70 & Glisin & Serin \\
& & $\mathrm{Na}$ & 1,75 & Histidin & Treonin \\
& & $\mathrm{Zn}$ & 0,07 & Isoleusin & Valin \\
& & $\mathrm{Cu}$ & 0,01 & Leusin & \\
& & $\mathrm{Mn}$ & 0,12 & & \\
\hline
\end{tabular}

Sumber: Yong dkk. ${ }^{5}$ 
olahraga lari meningkatkan ketahanan olahraga pada laki-laki dewasa bukan atlet.

\section{Ucapan Terima Kasih}

Terima kasih kepada pimpinan dan mahasiswa dari Fakultas Pendidikan Olahraga dan Kesehatan Universitas Pendidikan Indonesia (FPOK UPI) yang telah membantu pelaksanaan penelitian ini.

\section{Daftar Pustaka}

1. Kemenkes RI. Pembinaan kesehatan olahraga di Indonesia. Jakarta: Info Datin, Pusat Data dan Informasi Kementerian Kesehatan RI; 2015.

2. Von Duvillard SP, Braun WA, Markofski M, Beneke R, Leithäuser R. Fluids and hydration in prolonged endurance performance. Nutrition. 2004;20(7-8):651-6.

3. Ronald H. Metoda rehidrasi USATF sebagai metode alternatif pemulihan cairan tubuh. Seminar Nasional 2: Revitalisasi Penjas Melalui Pembenahan Citra Paradigmatis, Esensi Filosofis serta Struktur Kelembagaan. Bandung, 21-22 Desember 2009 [diunduh 21 Mei 2016]. Tersedia dari: http://tinyurl. com/ronald-seminar-upi.

4. Kalman DS, Feldman S, Krieger DR, Bloomer RJ. Comparison of coconut water and carbohydrate-electrolyte sport drink on measures of hydration and physical performance in exercise-trained men. J Int Soc Sports Nutr. 2012;9:1.

5. Yong JW, Ge L, Ng YF, Tan SN. The chemical composition and biological properties of coconut (Cocos nucifera L.) water. Molecules. 2009;14(12):5144-64.

6. Reddy EP, Lakshmi TM. Coconut waterproperties, uses, nutritional benefits in health and wealth and in health and disease: a review. JCTMB. 2014;2(2):6-18.

7. da Silva SC, Monteiro WD, Farinatti PTV. Exercise maximum capacity assessment: a review on the traditional protocols and the evolution to individualized models. Rev Bras Med Esporte. 2011;17(5):363-9.

8. Aragón-Vargas LF, Madriz-Dávila K. Incomplete warm-climate, post-exercise rehydration with water, coconut water or a sports drink. Med Sci Sports Exerc. 2000: 32(5):S238.

9. Saat M, Singh R, Sirisinghe RG, Nawawi M. Rehydration after exercise with fresh young coconut water, carbohydrate-electrolyte beverage and plain water. J Physiol Anthropol Appl Human Sci. 2002;21(2):93-104.

10. Ismail I, Singh R, Sirisinghe RG. Rehydration with sodium enriched coconut water after exercise-induced dehydration. Southeast Asian J Trop Med Public Health. 2007;38(4): 769-85.

11. Laitano O, Trangmar SJ, Marins DM, Menezes ES, da Silva RG. Improved exercise capacity in the heat followed by coconut water consumption. Motriz Rev Educ Fis. 2014;20(1):107-11.

12. Bonetti DL, Hopkins WG. Effects of hypotonic and isotonic sports drinks on endurance performance and physiology. Sport Sci. 2010; 14:63-70. 